\title{
The effect of roles prescribed by active ageing on quality of life across European regions
}

\author{
Martin Lakomý1,2 (D) \\ ${ }^{1}$ Faculty of Business and Economics, Mendel University in Brno, Brno, Czech Republic and ${ }^{2}$ Department of \\ Sociology, Faculty of Social Studies, Masaryk University, Brno, Czech Republic. Email: lakomy@mendelu.cz
}

(Accepted 27 April 2021; first published online 8 July 2021)

\begin{abstract}
The active ageing approach supports a set of roles or activities that are supposed to be beneficial for older adults. This paper reassesses the benefits of activities for the quality of life by (a) analysing many activities at the same time to control each other, (b) using panel data to detect the effects of activities over time, and (c) performing separate analyses for four European regions to test the context-specificity of the effects. The effects of roles in later life are tested on panel data from three waves of the Survey of Health, Ageing and Retirement in Europe (SHARE) project. The results of fixed-effects regression show that only some activities - volunteering, participating in a club and physical activity - increase the quality of life, and that care-giving within the household has the opposite effect. Moreover, the beneficial effects are much weaker and less stable than the other types of regression suggest; they are beneficial only in some regions, and their effect is much weaker than the effects of age, health and economic situation. Therefore, the active ageing approach and activity theory should reflect the diverse conditions and needs of older adults to formulate more-context-sensitive and less-normative policy recommendations.
\end{abstract}

Keywords: roles; older age; active ageing; quality of life; social norms; causality

\section{Introduction}

Promoting employment and social participation amongst older people is the dominant reaction to population ageing both in the academic sphere and in social policies. A higher level of productive social roles consisting of regular activities in later life is usually presented as a generally beneficial solution to challenges connected with population ageing (overload of social and health systems, poor health and lower quality of life (QoL)). Moreover, these challenges would be addressed to both older adults in the form of personal conditions improvement and society through more paid and unpaid work being done (Walker and Maltby, 2012; Timonen, 2016; Marsillas et al., 2017). Participation in society in later life is beneficial to older people themselves. For older people, social participation has an enhancing effect on their physical health (Thomas, 2011, 2012), mental

(C) The Author(s), 2021. Published by Cambridge University Press. This is an Open Access article, distributed under the terms of the Creative Commons Attribution licence (http://creativecommons.org/licenses/by/4.0/), which permits unrestricted re-use, distribution, and reproduction in any medium, provided the original work is properly cited. 
health (Engelhardt et al., 2010; Olesen and Berry, 2011) and life satisfaction (Gergen and Gergen, 2006; Adams et al., 2011; Potočnik and Sonnentag, 2013), mitigating also the intergenerational conflict in a society (Hess et al., 2017).

The notion of activities as a way to make population ageing sustainable and even beneficial has been the main assumption of the 'activity theory' (Havighurst, 1961) and the concept of active ageing (Walker, 2002). Since the active ageing approach has been built on the assumptions of the activity theory and both approaches expect prevalently positive outcomes of activities in later life, this study tests the assumptions of both approaches whilst referring mostly to the more recent and influential active ageing approach. In large part, the concept of active ageing was developed by the World Health Organization (WHO, 2002) and the European Union (EU) (Commission of the European Communities, 2002). Whilst the active ageing approach has been dominating the European and other geographical contexts, a similar meaning is connected to successful ageing influential in the United States of America, which also aims for more healthy and engaged later life through high social activity (Havighurst, 1961; Phillips et al., 2010; Rowe and Kahn, 2015).

The paper mainly aims to assess the impact on the subjective QoL of activities supported by the active ageing approach while controlling for other roles and external conditions. The analysis of the Survey of Health, Ageing and Retirement in Europe (SHARE) follows changes in employment, social participation, physical activities and care-giving over time and their effect on the QoL whilst controlling for each other. In this way, the study identifies the independent utility of the activities for older adults' QoL controlling for other activities in the same models.

\section{Activities supported by the active ageing approach and their expected outcomes}

Activities encompassed by active ageing differ by the information source, but the EU mainly supports prolonged employment, participation in society and independent living. The category 'participation in society' includes care-giving, volunteering, lifelong learning and political activities (EU Council, 2012; Eurostat, 2012). This diverse list of activities is connected by their presumed utility for both individuals (Walker, 2009; Adams et al., 2011; European Commission, 2013; Marsillas et al., 2017) and society (EU Council, 2012; European Commission, 2013; Foster and Walker, 2015). This study tests their utility, which is not supported conclusively because specific activities have different consequences for the QoL in different economic, institutional and cultural contexts (Adams et al., 2011; Neuberger and Haberkern, 2014; Di Novi et al., 2015; Lakomý, 2019).

The EU vigorously supports active ageing policies, which have resulted in thousands of events and programmes at all geographical levels of the European continent. The development of the Active Ageing Index (AAI) as a multi-dimensional operationalisation measuring active ageing across countries was amongst the most ambitious and influential projects implementing active ageing (European Commission, 2013; Sidorenko and Zaidi, 2013; Vidovićová, 2018). The values of the AAI for each country and region are published every two years in order to indicate 'the untapped potential of older people for more active participation in 
economic and social life' (Zaidi et al., 2018a: 3). Importantly, the large-scale AAI project suggests the following two points. Firstly, all targeted activities are intended to spread over time with individuals expected to perform as many roles as possible. Secondly, no cultural, institutional or economic differences within the EU are sufficiently considered by the uniform set of supported activities.

QoL is a key outcome of this study because its improvement in older adults besides the improvement of health and independence - is the central goal of active ageing, as well as of other approaches focused on the older population (Walker, 2004; Paúl et al., 2012; United Nations, 2013; Marsillas et al., 2017). The concept of QoL is a complex research phenomenon due to its amorphous and multidimensional nature, which is reflected differently by several competing paradigms (Walker, 2005). This study uses the CASP scale as the theoretically and empirically grounded measurement of subjective QoL in later life, which is further discussed in the methodological section.

Some proponents of active ageing present empirical evidence on the benefits of roles supported by active ageing to QoL (Reichert and Weidekamp-Maicher, 2004; Walker, 2005; Katz, 2009; Marsillas et al., 2017), but this empirical evidence usually comes from the most prosperous countries and is obtained from cross-sectional data. Moreover, the effect of various roles differs (Siegrist and Wahrendorf, 2009; Potočnik and Sonnentag, 2013), with identical roles having various outcomes across macro-contexts (Adams et al., 2011; Neuberger and Haberkern, 2014; Di Novi et al., 2015), which should also appear in the region-specific models including all important activities.

\section{Theoretical approaches applied to activity outcomes}

The proponents of active ageing aim for an increasing prevalence of all activities and expect the effect of activities on QoL to be positive regardless of other factors (Walker, 2009; United Nations Economic Commission for Europe and European Commission, 2015; Zaidi et al., 2017; Varlamova, 2018). However, an increasing amount of empirical findings show that the outcomes of each activity in older ages depend on its content and micro/macro-context (Adams et al., 2011; Di Gessa and Grundy, 2013; Neuberger and Haberkern, 2014; Lakomý, 2019, 2020). The outcomes of activities varying from positive to negative are expected by neither the active ageing approach nor the activity theory. However, more recent adjustments to the active ageing approach and activity theory claim that only personally meaningful and freely chosen activities improve QoL in later life (Musick and Wilson, 2003; Rozanova et al., 2012; Foster and Walker, 2015). This revised version of the whole activity approach makes it possible to expect varying outcomes of activities although many publications, and especially policy tools, do not take this revision into account (Timonen, 2016; Marsillas et al., 2017; Zaidi et al., 2018b).

The active ageing approach and activity theory are based on a set of role theories (George, 1993). The theory of role accumulation expecting beneficial outcomes of additional roles (Sieber, 1974), the theory of role strain expecting harmful outcomes (Goode, 1960), the continuity theory (Atchley, 1989), etc. These approaches assume that individual identities are developed and maintained through social roles. Based 
on this point of departure, the activity theory assumes that older adults need to maximise their activities - especially after the retirement exit - in order to maintain the sense of identity through performance of (meaningful) roles (Havighurst, 1961; Nimrod, 2007). Hence, especially roles in the area of part-time/flexible jobs, caregiving and social participation (such as volunteering) are stressed to bring the potential to enhance identity and improve the QoL, if they are normatively supported (Neuberger and Haberkern, 2014; Di Novi et al., 2015) and individually meaningful (Adams et al., 2011; Rozanova et al., 2012).

In contrast to the role approaches, social identity theory, rather than the importance of relatively stable roles and role expectations for individual identity, stresses the more-flexible group memberships (Tajfel and Turner, 1979; Hornsey, 2008: 210). Categorisation through social participation into groups enables an improvement of self-concept - and ultimately of subjective QoL - through comparison to other groups, such as older people not performing the activity. Moreover, social categorisation into social groups alters the choice of other activities and overall outcomes of any roles, as 'the norms of relevant ingroups are a crucial source of information about appropriate ways to think, feel, and act' (Hornsey, 2008). Nevertheless, the assumption of these mechanisms is an adequate salience of a given group, which may be not fulfilled by occasionally visiting a sports club or third-age university. Generally, the social identity theory would assume that it is particularly activities within positively evaluated social groups that improve the QoL of older adults. Furthermore, this approach can account for the variation of outcomes both within and amongst countries and welfare states due to emphasising the normativity of cognition and behaviour based on group values (Hornsey, 2008; Hogg, 2016).

\section{Empirical evidence on the effects of activities and their interdependencies}

The roles in later life are interdependent because both conflicts (Goode, 1960) and complementarities (Sieber, 1974) amongst roles are the usual phenomena. Furthermore, group membership and connected social norms also vary in their salience (Hornsey, 2008; Sets and Burke, 2010). A change in one role can affect the outcome of others; thus, all key roles in later life should be contained in the same model when their impact on QoL is evaluated.

The existing research suffers from several gaps stemming from the issues discussed above. Firstly, many papers have examined the effect of employment/retirement (Latif, 2011; Di Gessa and Grundy, 2013; Horner, 2014), provision of care (Colombo et al., 2011; Broese van Groenou et al., 2013) and activities of social participation (Adams et al., 2011; Cattan et al., 2011) on QoL. This common research design examining the effect of one type of activity ignores their interconnections. Secondly, some research controlled the labour force participation, whilst evaluating the effect of care-giving on QoL (Neuberger and Haberkern, 2014; Di Novi et al., 2015; Lakomý, 2020). Nevertheless, these studies still do not cover many key activities, and use only cross-sectional data. Thirdly, some authors studied the dependencies amongst different activities in older ages, but did not analyse their effect on any outcome (Burr et al., 2005, 2007; Arpino and Bordone, 2017, 2018). 
Arpino and Bordone (2017) argue that competition amongst activities should be reflected by active ageing approach. However, only the study of Potočnik and Sonnentag (2013) not following changes over time has included all the main types of activities in later life in one model, which this paper aims to address. Hence, the paper expands the existing body of literature by (a) reflecting various outcomes of activities under different societal settings, (b) controlling for other activities, and (c) utilising the possibilities of the cross-national panel data.

\section{The effects of activities and their variation across social contexts}

The role outcomes may depend not only on the characteristics of an individual or on their compatibility with other roles, but also on the context connected to the prevalence, meaning, form and tradition of specific activities (Pines et al., 2011; Rozanova et al., 2012; Timonen, 2016; de São José et al., 2017). The economic, institutional and cultural conditions in a given country shape the outcomes of different activities to various degrees and the next paragraphs aim to identify the essential macro-factors for each type of activity available in the literature.

Labour force participation as a role highly emphasised by active ageing policies (Foster and Walker, 2015; Madero-Cabib and Kaeser, 2016) seems more beneficial in less-wealthy countries as a way to maintain living standards (Borges Neves et al., 2013; Hofäcker, 2015; Lakomý, 2019). The level of labour force participation in later life in a country is shaped by the statutory retirement age, which does not vary much across European countries (Trading Economics, 2017), with this variation being mostly explained by the varying life expectancy (Salomon et al., 2012). This activity has positive effects for older adults according to some studies (Daatland et al., 2010; Di Gessa and Grundy, 2013), whilst other found negative (Latif, 2011; Horner, 2014; Gorry et al., 2015) or context-dependent effects (Borges Neves et al., 2013; Lakomý, 2019) of working longer. Regarding the contextual variation, Borges Neves et al. (2013) find that active employment reduces depression of older adults in countries of southern and central Europe as opposed to western and northern Europe. Similarly, Lakomý (2019) indicated the positive effect of labour force participation in southern and post-communist Europe and the negative effect in northern and western Europe, with the pension adequacy as the most suitable explanation of these regional differences.

The previous research has found a rather positive effect of less-intensive (Potočnik and Sonnentag, 2013; Lakomý, 2020) and negative effect of more-intensive and personal care-giving (Colombo et al., 2011; Broese van Groenou et al., 2013; Kaschowitz and Brandt, 2017) and this paper keeps the distinction. The provision of care can be more beneficial in countries with stronger familial norms (Neuberger and Haberkern, 2014; Di Novi et al., 2015). This difference seems attributable to the concept of structured ambivalence. The structured ambivalence, inspired by the concept of sociological ambivalence (Merton, 1976) and coined by Connidis and McMullin (2002a, 2002b), expects that roles fitting the social norms lead to subjective outcomes better than those of non-fulfilment of normative expectations. Therefore, various types of care-giving are more beneficial in macro-contexts more appreciating the role of the care-giver and punishing its avoidance via stronger familial norms (Neuberger and Haberkern, 2014). 
Moreover, care-giving can be more beneficial in countries where formal care is more available, which makes informal care-giving less focused on intensive personal care dictated by circumstances. Formal care seems especially important in splitting the responsibilities for a dependent older relative with family (Daatland and Lowenstein, 2005; Brandt et al., 2009; Lakomý, 2020). The paper by Di Novi et al. (2015) is a rare example of a detailed study on the contextual variation of caregiving outcomes, which found a beneficial effect of care provision on subjective QoL in southern Europe (normative appreciation), detrimental effect in continental Europe (lower normative support and lower availability of formal care) and no effect in northern Europe (lower normative support and higher formal care availability).

The effect of social participation is - compared to the ambiguous effect of caregiving and labour force participation - generally positive (Adams et al., 2011; Cattan et al., 2011; Potočnik and Sonnentag, 2013). Social participation is the group encompassing the rest of the activities studied although physical activity or volunteering do not necessarily have the social dimension. The social participation is usually supported by civic norms in society (Curtis et al., 2001; Hank, 2011; Wiertz and Lim, 2019), which stem from the cultural, political and religious tradition of a given society (Hank, 2011), and is higher in more-developed countries and more-stable democratic regimes (Curtis et al., 2001; Hooghe et al., 2016; Nikolova et al., 2017). The concept of structured ambivalence applied to social participation would mean that the activities of social participation have a more-positive effect in more-developed civic societies, in which they are more appreciated.

\section{Hypotheses and their justification}

Addressing all the main roles and other characteristics within an individual in panel data, this paper hypothesises:

- Hypothesis 1: The effect of labour force participation on subjective QoL is negligible.

- Hypothesis 2: The effect of care-giving outside the household on subjective QoL is positive.

- Hypothesis 3: The effect of care-giving within the household on subjective QoL is negative.

- Hypothesis 4: The effect of activities usually performed in groups and designated as social participation on subjective QoL is positive.

Most importantly, the variation across contexts is expected for all overall effects:

- Hypothesis 5: The effect of labour force participation on subjective QoL is more positive in less-prosperous regions.

- Hypothesis 6: The effect of care-giving outside the household on subjective QoL is more beneficial in regions with stronger familial norms.

- Hypothesis 7: The effect of care-giving within the household on subjective QoL is more beneficial in regions with higher accessibility of formal care.

- Hypothesis 8: Types of social participation have a more-positive effect on subjective QoL in regions with stronger civic norms. 
Hypotheses 1-4 address the overall effects of activities and stem primarily from the cited empirical evidence. The activity theory would assume positive effects of all (at least all meaningful) activities (Havighurst, 1961; Adams et al., 2011), whilst the social identity theory expects beneficial outcomes of activities within positively evaluated social groups (Tajfel and Turner, 1979; Hornsey, 2008), which contains social participation and, to some extent, labour force participation as well. Hypothesis 5 is based on the assumption of more beneficial labour force participation in less-wealthy countries as a way to maintain the living standard in later life (Borges Neves et al., 2013; Hofäcker, 2015; Lakomý, 2019). Hypothesis 6 follows the logic of structured ambivalence (Connidis and McMullin, 2002b; Neuberger and Haberkern, 2014), expecting the care-giving outside the household to be more beneficial in regions with a higher social appreciation of this activity. In contrast, the care-giving within the household is expected to be more beneficial in the conditions of more-accessible formal care (Hypothesis 7), with the responsibilities for a dependent older relative shared by the family (Daatland and Lowenstein, 2005; Brandt et al., 2009; Lakomý, 2020). Finally, Hypothesis 8 also uses the argument of structured ambivalence, but this time for social participation and its higher appreciation in the conditions of stronger civic norms (Curtis et al., 2001; Hank, 2011; Wiertz and Lim, 2019).

\section{Data, methods and variables}

\section{Data and sample}

This study uses data from the SHARE project, which is a large European project in which respondents from nationally representative samples of the population over 50 years and their spouses are interviewed every two years (Börsch-Supan et al., 2013; Börsch-Supan, 2017). The SHARE data from Waves 4, 5 and 6 provide recent information from three time-points in a medium timespan, which capitalise on the panel dimension of the data and provide enough within-person variation to control for unobserved heterogeneity. Furthermore, more countries participated in these subsequent waves than in the previous ones. The selected analytical approach uses only observations present in all waves of measurement, and thus it would be problematic to use more than three consecutive waves due to a low number of countries and respondents participating continually over a longer time. Finally, each of the waves misses some countries participating in SHARE, which disqualifies these countries for the analysis.

The countries listed in the study are categorised by their welfare regimes as defined by Esping-Andersen (1990) and other scholars developing this typology (Ferrera, 1996; Fenger, 2007; Ebbinghaus, 2012) into four European regions. The welfare regimes typology is often used in social sciences research (Ebbinghaus, 2012; Kammer et al., 2012; Hansen and Slagsvold, 2016; Sirovátka et al., 2019) for reasons similar to this study. The paper finds this typology very useful due to its grouping of countries similar in welfare politics, geographic location, economic, institutional and cultural settings, the prevalence of activities, the average level of QoL and other vital macro-factors (Walker, 2004; Eikemo et al., 2008; Borges Neves et al., 2013; Di Novi et al., 2015; Sirovátka et al., 2019). Hence, the typology is used for identifying groups of countries rather than for examining the effect of 
the welfare state as such. The final sample consists of data from $11 \mathrm{EU}$ countries divided in line with the welfare regimes typology (Esping-Andersen, 1990) into social-democratic countries (Denmark and Sweden), conservative countries (Austria, Belgium, France and Germany), Mediterranean countries (Italy and Spain) and post-communist countries (Czech Republic, Estonia and Slovenia) for the more context-specific part of the analysis.

This study covers respondents aged 51-86 in Wave 4 of 2011 (age range 55-90 in Wave 6 of 2015), because active ageing addresses the chronological age as a flexible characteristic and directs its policies at all groups of older adults (Timonen, 2016; de São José et al., 2017; Zaidi and Howse, 2017). The respondents aged 90 + in Wave 6 (about 2\%) were dropped in order to prevent any distortion of the results by outliers with different characteristics and living conditions. The panel attrition in the sample was 32.2 per cent between Waves 4 and 5 and 23.8 per cent between Waves 5 and 6 . A total of 28,283 respondents met the age definition and participated in all three waves, including 11,191 respondents not asked questions about care-giving in Waves 4 or 5 (being not family respondents) and 3,567 had at least one more missing value. Hence, the final balanced sample consists of 13,525 individuals present in all three waves. Although the drop in the number of respondents who were not family respondents may seem large, this step ensures that people living with a partner are not overrepresented, and only one member of every household is present in the final sample. The sensitivity analyses revealed that changes in the definition of the sample or the way of dealing with the missing values do not substantially alter the findings.

The baseline characteristics of the panel sample are displayed in Table 1. The table contains descriptive statistics of the whole sample, but also of the four European regions separately, as this grouping is used in the analysis. On the whole, some activities are more prevalent amongst older adults - labour force participation, care provided outside households and physical activity - whilst caregiving within the household, educational courses and participation in political organisations are rare. Regarding regional differences, all activities except for caregiving within households are most prevalent in social-democratic countries (levelling conservative countries in volunteering and political participation), whilst the opposite is true for Mediterranean countries. Conservative and post-communist welfare states fall in between, with most of the activities being carried out more often in conservative countries. The regions are similarly ordered in other individual characteristics, with social-democratic countries having higher mean age, higher level of education, QoL, better health and better financial situation. Mediterranean countries and postcommunist countries can be found at the opposite end of the spectrum.

\section{Method}

The analysis uses panel data from three waves of SHARE with the continuous outcome variable. The methodological approach capitalises on combining the selection into specific activities and the consequences for QoL over time. All models use the enter (not stepwise) method with inserting all variables simultaneously. The data structure has two levels-observations in time nested in the individual-and some parts of the analysis are also sorted by the European region. An alternative 
Table 1. Descriptive statistics of the baseline characteristics of 13,525 respondents available for analysis in the Survey of Health, Ageing and Retirement in Europe (SHARE), Waves 4,5 and 6 , sorted by welfare regime

\begin{tabular}{|c|c|c|c|c|c|c|}
\hline Variable & $\begin{array}{l}\text { Categories or } \\
\text { range }\end{array}$ & Total & $\begin{array}{l}\text { Social-democratic } \\
\text { countries }\end{array}$ & $\begin{array}{l}\text { Conservative } \\
\text { countries }\end{array}$ & $\begin{array}{l}\text { Mediterranean } \\
\text { countries }\end{array}$ & $\begin{array}{l}\text { Post-communist } \\
\text { countries }\end{array}$ \\
\hline & & \multicolumn{5}{|c|}{ Percentages or mean values } \\
\hline Quality of life: CASP-12 (mean) & $13-48$ & 37.3 & 40.3 & 38.4 & 34.9 & 36.2 \\
\hline Labour force participation & Yes & 30.7 & 41.9 & 30.3 & 23.5 & 30.6 \\
\hline Care-giving outside household & Yes & 41.2 & 48.2 & 41.7 & 36.5 & 40.4 \\
\hline Care-giving within household & Yes & 5.8 & 3.6 & 5.0 & 8.8 & 6.1 \\
\hline Volunteering & Yes & 14.2 & 20.3 & 21.0 & 8.8 & 7.1 \\
\hline Educational course & Yes & 7.4 & 11.1 & 9.3 & 3.7 & 5.5 \\
\hline Sport or social club & Yes & 27.1 & 46.6 & 31.1 & 13.3 & 21.9 \\
\hline Political organisation & Yes & 4.4 & 6.0 & 6.1 & 2.0 & 3.0 \\
\hline Physical activity & Yes & 58.3 & 65.8 & 58.1 & 42.2 & 62.9 \\
\hline Age (mean) & $51-86$ & 65.6 & 65.7 & 65.2 & 66.3 & 65.6 \\
\hline Partner in the household & Yes & 55.8 & 60.9 & 51.8 & 66.4 & 54.0 \\
\hline \multirow[t]{4}{*}{ Able to make ends meet } & Great difficulty & 10.7 & 2.4 & 6.7 & 16.8 & 15.3 \\
\hline & Some difficulty & 28.5 & 10.8 & 21.4 & 36.7 & 38.8 \\
\hline & Fairly easily & 33.9 & 29.9 & 38.5 & 32.4 & 30.8 \\
\hline & Easily & 27.0 & 57.0 & 33.6 & 14.2 & 15.1 \\
\hline \multirow[t]{5}{*}{ Subjective health status } & Poor & 9.3 & 4.7 & 6.1 & 9.6 & 14.4 \\
\hline & Fair & 29.6 & 17.6 & 23.8 & 31.1 & 39.4 \\
\hline & Good & 36.2 & 25.2 & 40.9 & 40.4 & 32.8 \\
\hline & Very good & 17.3 & 31.5 & 20.7 & 14.4 & 10.0 \\
\hline & Excellent & 7.6 & 21.0 & 8.6 & 4.5 & 3.5 \\
\hline
\end{tabular}




\begin{tabular}{|c|c|c|c|c|c|c|}
\hline Gender & Male & 37.1 & 43.1 & 40.5 & 37.0 & 31.3 \\
\hline & Female & 62.9 & 56.9 & 59.5 & 63.0 & 68.7 \\
\hline \multirow[t]{3}{*}{ Education level } & ISCED 0,1 & 19.1 & 15.4 & 16.8 & 52.0 & 9.1 \\
\hline & ISCED 2-4 & 56.8 & 46.0 & 53.3 & 39.6 & 71.4 \\
\hline & ISCED 5, 6 & 24.1 & 38.6 & 29.9 & 8.4 & 19.5 \\
\hline \multirow[t]{11}{*}{ Country } & Austria & 11.7 & & 30.3 & & \\
\hline & Belgium & 12.6 & & 32.4 & & \\
\hline & Czech Republic & 11.3 & & & & 32.2 \\
\hline & Denmark & 6.7 & 58.2 & & & \\
\hline & Estonia & 15.7 & & & & 45.0 \\
\hline & France & 10.9 & & 28.0 & & \\
\hline & Germany & 3.6 & & 9.3 & & \\
\hline & Italy & 7.4 & & & 50.1 & \\
\hline & Slovenia & 7.9 & & & & 22.8 \\
\hline & Spain & 7.4 & & & 49.5 & \\
\hline & Sweden & 4.8 & 41.8 & & & \\
\hline $\mathrm{N}$ & & 13,525 & 1,561 & 5,246 & 1,994 & 4,724 \\
\hline
\end{tabular}

Notes: The group of social-democratic countries consists of Denmark and Sweden, conservative countries consists of Austria, Belgium, France and Germany, Mediterranean countries consists of Italy and Spain and post-communist countries consists of the Czech Republic, Estonia and Slovenia. ISCED: International Standard Classification of Education.

Source: SHARE, Waves 4, 5 and 6, author's calculations. 
approach could be adding a third level of the multilevel data structure in the form of country, but 11 countries do not suffice for this step (Bryan and Jenkins, 2016). The hypothesised effects can be estimated through random- or fixed-effects regression in the two-level data structure, which are the two approaches compared in the analysis. The random-effects regression works on the same principle as the ordinary least squares regression and usually produces very similar results, whilst it is adjusted to the panel data structure and aims to model change over time. This technique uses both between-person and within-person variations, treating unobserved differences as random, which leads to higher efficiency at the expense of higher risk of bias (Allison, 2009).

In contrast, the fixed-effects regression uses only the within-person variation to estimate the coefficients (Allison, 2009). This procedure makes it possible to use every individual as their control, and thus it controls all stable (un)observable macro- and micro-characteristics. This robustness of the method is conditioned by a sufficient variation of predictors and their sufficient exogeneity (Windmeijer, 2000). A difference in coefficients between the random-effects model (REM) and fixed-effects model (FEM) indicates spurious effects in REM, whilst much higher standard errors in FEM result in a low efficiency of FEM estimation (Allison, 2009). The estimation of both models on the whole sample is, therefore, compared using the Hausman test, and the more-appropriate model in terms of efficiency and bias is used for the analysis of sub-groups, which is an approach similar to the one used by Kaschowitz and Brandt (2017) in the study of health effects of informal care-giving for older adults across Europe.

The fixed-effects regression is effective in some threats to causal inference such as selection and endogeneity bias (Allison, 2009; Hanchane and Mostafa, 2012; Brüderl and Ludwig, 2015). Still, it does not solve all aspects of endogeneity, including those related to time-invariant predictors (Cohen et al., 2003; Allison, 2005). Hence, the one time-variant predictor (health) is not included in FEM due to the risk of endogeneity confirmed by the Hausman test of endogeneity, with the all-time invariant predictors being excluded from FEM as well. The problem of endogeneity also relates to the assumption of temporal homogeneity, which can be relaxed if control groups and time dummies are included in the analysis (Brüderl and Ludwig, 2015). Regarding the alternatives, the random-effect-within-between model provides more analytical options at the expense of a higher risk of bias connected to the normality assumption (Bell et al., 2019), but these are not needed in the presented analysis. Therefore, a fixed-effects regression is used by this research as superior for evaluating causal effects in this specific design (Gunasekara et al., 2014; Brüderl and Ludwig, 2015; Bell et al., 2019), whilst the results should be replicated by alternative techniques in future research.

Regarding the data structure, the paper uses balanced data with respondents having fewer than three observations in the time being dropped. Table 2 shows two types of predicted probabilities - the probability to end and probability to start a given activity - with the absolute frequency of these transitions in parentheses. These data illustrate that transition from most of the activities is much more probable than transition into activities, but the frequencies of starting and ending particular activities do not differ substantially (except for labour force participation). Computing two types of transformation for each activity would give a 
Table 2. Transition probabilities of activities (and number of changes in parentheses) between two consecutive waves for 27,050 possible changes in time

\begin{tabular}{|c|c|c|c|c|c|c|}
\hline Activity & $\begin{array}{l}\text { Type of } \\
\text { transition }\end{array}$ & $\begin{array}{l}\text { Social-democratic } \\
\text { countries }\end{array}$ & $\begin{array}{l}\text { Conservative } \\
\text { countries }\end{array}$ & $\begin{array}{l}\text { Mediterranean } \\
\text { countries }\end{array}$ & $\begin{array}{l}\text { Post-communist } \\
\text { countries }\end{array}$ & Total \\
\hline \multirow{2}{*}{$\begin{array}{l}\text { Labour force } \\
\text { participation }\end{array}$} & $0 \rightarrow 1$ & $0.015(28)$ & $0.012(92)$ & $0.019(60)$ & $0.023(158)$ & $0.017(338)$ \\
\hline & $1 \rightarrow 0$ & $0.193(232)$ & $0.222(646)$ & $0.216(189)$ & $0.248(644)$ & $0.225(1,708)$ \\
\hline \multirow{2}{*}{$\begin{array}{l}\text { Care-giving outside } \\
\text { household }\end{array}$} & $0 \rightarrow 1$ & $0.249(404)$ & $0.215(1,301)$ & $0.198(500)$ & $0.228(1,255)$ & $0.221(3,460)$ \\
\hline & $1 \rightarrow 0$ & $0.324(487)$ & $0.333(1,481)$ & $0.448(655)$ & $0.377(1,487)$ & $0.362(4,110)$ \\
\hline \multirow{2}{*}{$\begin{array}{l}\text { Care-giving within } \\
\text { household }\end{array}$} & $0 \rightarrow 1$ & $0.024(71)$ & $0.036(356)$ & $0.060(218)$ & $0.044(389)$ & $0.041(1,034)$ \\
\hline & $1 \rightarrow 0$ & $0.708(68)$ & $0.604(329)$ & $0.638(231)$ & $0.624(378)$ & $0.625(1,006)$ \\
\hline \multirow[t]{2}{*}{ Volunteering } & $0 \rightarrow 1$ & $0.083(206)$ & $0.094(781)$ & $0.042(153)$ & $0.046(403)$ & $0.066(1,543)$ \\
\hline & $1 \rightarrow 0$ & $0.335(212)$ & $0.368(808)$ & $0.467(161)$ & $0.636(411)$ & $0.417(1,592)$ \\
\hline \multirow[t]{2}{*}{ Educational course } & $0 \rightarrow 1$ & $0.066(185)$ & $0.049(468)$ & $0.020(75)$ & $0.028(253)$ & $0.039(981)$ \\
\hline & $1 \rightarrow 0$ & $0.623(210)$ & $0.573(525)$ & $0.739(99)$ & $0.622(298)$ & $0.606(1,132)$ \\
\hline \multirow[t]{2}{*}{ Sport or social club } & $0 \rightarrow 1$ & $0.267(437)$ & $0.149(1,077)$ & $0.073(254)$ & $0.101(750)$ & $0.127(2,518)$ \\
\hline & $1 \rightarrow 0$ & $0.229(340)$ & $0.345(1,127)$ & $0.586(303)$ & $0.440(886)$ & $0.364(2,656)$ \\
\hline \multirow{2}{*}{$\begin{array}{l}\text { Political } \\
\text { organisation }\end{array}$} & $0 \rightarrow 1$ & $0.048(139)$ & $0.037(363)$ & $0.020(79)$ & $0.023(206)$ & $0.031(787)$ \\
\hline & $1 \rightarrow 0$ & $0.630(131)$ & $0.482(329)$ & $0.649(61)$ & $0.652(187)$ & $0.557(708)$ \\
\hline \multirow[t]{2}{*}{ Physical activity } & $0 \rightarrow 1$ & $0.406(417)$ & $0.293(1,325)$ & $0.293(662)$ & $0.348(1,262)$ & $0.321(3,666)$ \\
\hline & $1 \rightarrow 0$ & $0.188(393)$ & $0.273(1,630)$ & $0.366(632)$ & $0.278(1,618)$ & $0.273(4,273)$ \\
\hline $\begin{array}{l}\mathrm{N} \text { of potential } \\
\text { changes }\end{array}$ & & 3,122 & 10,492 & 3,988 & 9,448 & 27,050 \\
\hline
\end{tabular}

Note: The group of social-democratic countries consists of Denmark and Sweden, conservative countries consists of Austria, Belgium, France and Germany, Mediterranean countries consists of Italy and Spain and post-communist countries consists of the Czech Republic, Estonia and Slovenia.

Source: Survey of Health, Ageing and Retirement in Europe (SHARE), Waves 4, 5 and 6, author's calculations. 
total number of changes important for the feasibility of FEM, which use only within-person variation. This indicator shows enough changes of explanatory variables between two consecutive waves for each European region; the lowest number of changes is for care-giving within the household in social-democratic countries and participation in a political organisation in Mediterranean countries (139 and 140 changes, respectively).

\section{Dependent variable}

QoL has been conceptualised and measured in many ways concerning societal, individual or both types of influences. This paper examines the theoretically grounded and empirically tested CASP-12 scale (Higgs et al., 2003; Hyde et al., 2003), which was designed as opposed to the practice of measuring QoL in older ages by health or longevity. CASP is based on four ontologically grounded domains of QoL in older ages based on the pyramid of needs (Maslow, 1943) and aspires to be a scale that provides a comparable score across societal contexts (Higgs et al., 2003; Hyde et al., 2003). Although each of these domains stands by itself, control and autonomy together reflect the ability to intervene in the environment and be free of excessive external intervention, whilst self-realisation and pleasure indicate the presence of satisfying and meaningful activities in a person's life (Higgs et al., 2003; Platts et al., 2015).

Although Borrat-Besson et al. (2015) raised some concerns on the comparability of CASP-12 across SHARE countries and the consistency of the autonomy domain, the scale is still the most developed indicator of QoL adjusted for the older population. Then, the CASP-12 scale was designed for the measurement of QoL in younger old age (Higgs et al., 2003; Hyde et al., 2003), being also applicable to very old adults (Gjonça et al., 2010; Lakomý and Petrová Kafková, 2017) due to the overlapping life priorities of these two phases (Baltes and Smith, 2003; Krause, 2007). Each of the four domains is measured using three items on a fourpoint scale. Hence, the CASP-12 scale can take values between 12 and 48 and captures the multi-dimensional nature of the concept. Furthermore, this variable makes it possible to estimate models based on linear regression that predict the values of CASP based on explanatory and control variables using the value changes across the waves.

\section{Main explanatory variables}

The present paper examines the effect of roles prescribed by active ageing, using all important activities as explanatory variables. The employed roles belong to various sections of the SHARE dataset with their measurement taking various forms. The aims of variable transformations were (a) to produce a simple binary indicator for each activity with sufficient within-person variation, and (b) to fit the measurement of any particular activity to its conceptualisation within the active ageing approach as well as possible.

The labour force participation was enquired about by the question 'In general, which of the following best describes your current employment situation?', with options listed. This indicator groups respondents into categories of economically 
active - employed, self-employed or unemployed - and economically inactive retired, home-makers, rentiers or permanently disabled (the latter one is the reference category). The category of unemployed is merged with working older adults, as unemployment is more similar to work than retirement in some of its outcomes (Lakomý and Kreidl, 2015) and unemployment is also connected to active ageing, which supports prolonged labour force participation without guaranteeing jobs (Timonen, 2016). Despite these arguments, some older workers may get discouraged by long-term unemployment (Rife and First, 1989; Maestas and Li, 2006; Axelrad et al., 2018) and experience a lower QoL. However, sensitivity analysis of REM and FEM, (a) dropping the unemployed from the models and (b) including unemployed older adults to the group of economically inactive, revealed no substantive differences in the results.

The 'care outside household' variable indicates care or help provided to any recipient monthly or more often, and 'care within household' indicates more intensive and personal care (daily is the only intensity measured by SHARE) for anybody living in the same household; not providing any care or help of monthly frequency is the reference. These two variables were constructed from a set of more-specific questions covering the type, recipient and frequency of each care-giving relationship. The care-giving outside household was asked in the form 'In the last twelve months, have you personally given any kind of help listed on this card to a family member from outside the household, a friend or neighbour?' and many other questions including looking after grandchild(ren). The indicator of care-giving within the household is based on the item 'Is there someone living in this household whom you have helped regularly during the last twelve months with personal care, such as washing, getting out of bed, or dressing?'

The variables for volunteering, educational courses, sports or social club, political organisation and physical activity indicate whether the respondent engages in an activity 'at least monthly' (value 1) or 'less often/not at all' (value 0 as the reference). The exact wording was 'How often do you engage in vigorous physical activity, such as sports, heavy housework, or a job that involves physical labour?' for an indicator of physical activity and 'Which of the activities listed on this card if any - have you done in the past twelve months?' for all other indicators. The other activities available in all three waves are 'volunteer or charity work', 'educational or training course', 'sport, social, or other kind of club' and 'participation in a political or community-related organisation'. Most of the measured activities take diverse content and meaning - this cannot be reflected by the data available, but the study aims to show the prevailing effect of each type of activity rather than the consequences of specific situations.

\section{Control variables}

Gender, education, country and other time-invariant variables are not included in FEM because they are controlled automatically. Thus, the FEM presented contain four time-variant control variables. Age is accompanied by age squared to identify a potentially non-linear effect - these two variables are centred on their mean to enable the interpretation of the intercept. The subjective economic situation is measured by the question 'Would you say that your household is able to make ends 
meet...' with the following options: with great difficulty (the reference category), with some difficulty, fairly easily and easily. The REM controls all variables of FEM and additionally gender, health, education and country. Subjective health status is also measured directly using the options of poor (reference), fair, good, very good and excellent health. Gender has the categories male $=0$ (reference) and female $=1$, the level of education, as measured by the International Standard Classification of Education (ISCED) scale, divides respondents into groups with primary (ISCED 0, 1; reference), secondary (ISCED 2-4) and tertiary education (ISCED 5, 6). Finally, the country is included in the REM as a set of binary variables.

\section{Results}

\section{Comparison of REM and FEM}

Table 3 presents the REM and FEM for the whole sample. REM shows five significantly positive effects (ranging from 0.180 to 0.647 ) and one negative effect $(-1.246)$ of performed roles on subjective QoL, which means that most of the examined activities increase QoL over time. Specifically, labour force participation, volunteering, physical activity, engagement in a sports club and participation in a political organisation are beneficial for QoL, which supports the assumptions of the active ageing approach. Only care-giving within the household has a negative effect; the coefficients of care provided outside the household and attendance of educational courses are not significant. Men, older adults with a higher level of education and those living with a partner have a higher QoL. Further, age has a non-linear effect, implying the increase of QoL with age followed by a reversed trend at a higher age, whilst the effects of a good financial situation and good health are presumably beneficial. However, FEM has the potential to identify spurious effects of REM connected to potential selection bias in REM.

The magnitude and significance of coefficients in FEM, which also indicate the impact of change over time, is much lower (Table 3). On the one hand, the positive coefficients from 0.280 to 0.347 still suggest that starting volunteering, physical activity or participation in a sports club between waves has a positive effect (and stopping them has a negative effect) on subjective QoL, whilst care-giving within the household decreases QoL. On the other hand, starting with labour force participation and organised political activity do not increase QoL in time, with even the significant coefficients for activities dropping substantially. Apart from a partner in the household, all control variables have significant fixed effects, although decreased in magnitude. The control variables could also be used in interactions with activities. For instance, the effect of activities could vary strongly by gender (Adams et al., 2011; Rozanova et al., 2012). However, the interactions are generally not significant, and the only notable difference based on gender is a slightly more positive effect of physical activities of men. Generally, the standard errors of most coefficients are 0.02-0.08 higher in FEM than in REM, which implies a lower efficiency of FEM. Moreover, the difference between the coefficients of these models signifies that a large part of the random effects can be accounted for by some timeinvariant factors controlled only in FEM. The difference between models being confirmed by the Hausman test with $<0.0001$, FEM provides less-effective estimation, but also less-biased results. 
Table 3. Random-effects and fixed-effects regression models predicting subjective quality of life

\begin{tabular}{|c|c|c|c|c|}
\hline & \multicolumn{2}{|c|}{ Random-effects model } & \multicolumn{2}{|c|}{ Fixed-effects model } \\
\hline & Coefficient & SE & Coefficient & SE \\
\hline Constant & $31.317^{\star \star \star}$ & 0.205 & $35.145^{\star \star \star}$ & 0.174 \\
\hline Labour force participation & $0.180^{\star}$ & 0.082 & -0.002 & 0.139 \\
\hline Care-giving outside household & 0.067 & 0.050 & -0.027 & 0.073 \\
\hline Care-giving within household & $-1.264^{\star \star \star}$ & 0.097 & $-1.056^{\star \star \star}$ & 0.152 \\
\hline Volunteering & $0.647^{\star \star \star}$ & 0.073 & $0.322^{\star \star}$ & 0.103 \\
\hline Educational course & 0.034 & 0.095 & -0.002 & 0.120 \\
\hline Sport or social club & $0.507^{\star \star \star}$ & 0.058 & $0.228^{\star \star}$ & 0.082 \\
\hline Political organisation & $0.246^{\star}$ & 0.111 & -0.003 & 0.151 \\
\hline Physical activity & $0.564^{\star \star \star}$ & 0.050 & $0.347^{\star \star \star}$ & 0.073 \\
\hline Age & $0.612^{\star \star \star}$ & 0.049 & $0.941^{\star \star \star}$ & 0.111 \\
\hline Age squared & $-0.005^{\star \star \star}$ & 0.000 & $-0.007^{\star \star \star}$ & 0.001 \\
\hline Partner in the household & $0.406^{\star \star \star}$ & 0.065 & 0.020 & 0.199 \\
\hline \multicolumn{5}{|c|}{ Able to make ends meet (Ref. With great difficulty): } \\
\hline With some difficulty & $1.619^{\star \star \star}$ & 0.083 & $1.182^{\star \star \star}$ & 0.132 \\
\hline Fairly easily & $3.394^{\star \star \star}$ & 0.088 & $2.441^{\star \star \star}$ & 0.147 \\
\hline Easily & $4.402^{\star \star \star}$ & 0.094 & $2.993^{\star \star \star}$ & 0.157 \\
\hline \multicolumn{5}{|c|}{ Subjective health status (Ref. Poor): } \\
\hline Fair & $2.721^{\star \star \star}$ & 0.086 & & \\
\hline Good & $4.641^{\star \star \star}$ & 0.090 & & \\
\hline Very good & $5.806^{\star \star \star}$ & 0.102 & & \\
\hline Excellent & $6.595^{\star \star \star}$ & 0.122 & & \\
\hline Gender (Ref. Male) & $-0.263^{\star \star \star}$ & 0.070 & & \\
\hline \multicolumn{5}{|l|}{ Education level (Ref. ISCED 0, 1): } \\
\hline ISCED 2-4 & $0.513^{\star \star \star}$ & 0.096 & & \\
\hline ISCED 5, 6 & $0.659^{\star \star \star}$ & 0.114 & & \\
\hline Country (10 dummy variables) & \multicolumn{4}{|l|}{ Not shown } \\
\hline $\mathrm{N}$ & \multicolumn{2}{|c|}{40,575} & \multicolumn{2}{|c|}{40,575} \\
\hline
\end{tabular}

Notes: SE: standard error. Ref.: reference category. ISCED: International Standard Classification of Education. Source: Survey of Health, Ageing and Retirement in Europe (SHARE), Waves 4, 5 and 6, author's calculations. Significance levels: ${ }^{\star} p<0.05,{ }^{\star \star} p<0.01,{ }^{\star \star \star} p<0.001$.

\section{Variation in FEM by welfare regime}

Table 4 shows the results of FEM as a less-biased method for each European region separately. The results show a robust positive effect of financial situation on QoL across regions, whilst the non-linear effect of age is not significant only in 
Table 4. Fixed-effects regression models predicting subjective quality of life sorted by European region

\begin{tabular}{|c|c|c|c|c|c|c|c|c|}
\hline & \multicolumn{2}{|c|}{$\begin{array}{l}\text { Social-democratic } \\
\text { countries }\end{array}$} & \multicolumn{2}{|c|}{$\begin{array}{l}\text { Conservative } \\
\text { countries }\end{array}$} & \multicolumn{2}{|c|}{$\begin{array}{l}\text { Mediterranean } \\
\text { countries }\end{array}$} & \multicolumn{2}{|c|}{$\begin{array}{l}\text { Post-communist } \\
\text { countries }\end{array}$} \\
\hline & Coefficient & SE & Coefficient & SE & Coefficient & SE & Coefficient & SE \\
\hline Constant & $36.578^{\star \star \star}$ & 0.634 & $36.220^{\star \star \star}$ & 0.304 & $32.190^{\star \star *}$ & 0.479 & $34.253^{\star \star \star}$ & 0.264 \\
\hline Labour force participation & -0.343 & 0.276 & -0.130 & 0.210 & 0.512 & 0.431 & 0.075 & 0.254 \\
\hline Care-giving outside household & -0.068 & 0.153 & -0.059 & 0.108 & 0.006 & 0.221 & 0.009 & 0.132 \\
\hline Care-giving within household & -0.160 & 0.358 & $-0.868^{\star \star \star}$ & 0.233 & $-1.272^{\star \star \star}$ & 0.360 & $-1.294^{\star \star \star}$ & 0.269 \\
\hline Volunteering & $0.448^{\star}$ & 0.225 & 0.258 & 0.143 & $1.008^{\star \star}$ & 0.378 & 0.137 & 0.210 \\
\hline Educational course & -0.110 & 0.218 & -0.065 & 0.167 & 0.394 & 0.561 & 0.060 & 0.251 \\
\hline Sport or social club & 0.136 & 0.172 & 0.075 & 0.118 & $1.266^{\star \star \star}$ & 0.294 & 0.292 & 0.158 \\
\hline Political organisation & 0.076 & 0.285 & 0.103 & 0.203 & -0.104 & 0.609 & -0.113 & 0.336 \\
\hline Physical activity & $0.348^{\star}$ & 0.173 & $0.327^{\star \star}$ & 0.111 & 0.341 & 0.205 & $0.326^{\star}$ & 0.131 \\
\hline Age & $1.107^{\star \star \star}$ & 0.239 & $0.708^{\star \star \star}$ & 0.166 & 0.517 & 0.337 & $1.323^{\star \star \star}$ & 0.202 \\
\hline Age squared & $-0.008^{\star \star \star}$ & 0.002 & $-0.005^{\star \star \star}$ & 0.001 & -0.004 & 0.002 & $-0.010^{\star \star \star}$ & 0.001 \\
\hline Partner in the household & -0.705 & 0.402 & 0.062 & 0.314 & 0.901 & 0.576 & -0.139 & 0.346 \\
\hline \multicolumn{9}{|c|}{ Able to make ends meet (Ref. With great difficulty): } \\
\hline With some difficulty & 0.832 & 0.559 & $1.130^{\star \star \star}$ & 0.253 & $1.210^{\star \star \star}$ & 0.279 & $1.066^{\star \star \star}$ & 0.193 \\
\hline Fairly easily & $1.637^{\star \star}$ & 0.581 & $2.466^{\star \star \star}$ & 0.267 & $2.345^{\star \star \star}$ & 0.333 & $2.364^{\star \star \star}$ & 0.219 \\
\hline Easily & $2.301^{\star \star \star}$ & 0.580 & $2.981^{\star \star \star}$ & 0.279 & $3.052^{\star \star \star}$ & 0.385 & $2.866^{\star \star \star}$ & 0.247 \\
\hline $\mathrm{N}$ & \multicolumn{2}{|c|}{4,683} & \multicolumn{2}{|c|}{15,738} & \multicolumn{2}{|c|}{5,982} & \multicolumn{2}{|c|}{14,172} \\
\hline
\end{tabular}

Notes: The group of social-democratic countries consists of Denmark and Sweden, conservative countries consists of Austria, Belgium, France and Germany, Mediterranean countries consists of Italy and Spain and post-communist countries consists of the Czech Republic, Estonia and Slovenia. Ref.: reference category.

Source: Survey of Health, Ageing and Retirement in Europe (SHARE), Waves 4, 5 and 6, author's calculations.

Significance levels: ${ }^{\star} p<0.05,{ }^{\star \star} p<0.01,{ }^{\star \star \star} p<0.001$. 
Mediterranean countries. In contrast, the coefficients for activities vary much more in the European context. Changes in labour force participation affect QoL in the opposite direction in social-democratic and Mediterranean countries, although these substantive effects $(-0.343$ and 0.512$)$ are not significant $(p=0.215$ and $p=0.235$ ) due to the lower effectiveness of the estimation. Care-giving within the household has a strong negative effect, -1.294 in post-communist countries, -1.272 in Mediterranean countries and -0.868 in conservative countries, but none in social-democratic countries. Starting volunteering between waves increases QoL only in social-democratic and Mediterranean countries, with both statistically and substantively significant coefficients, 0.448 and 1.008 . Participation in a sports or social club has a coefficient of 1.266 with $p<0.001$ in Mediterranean countries, but no effect whatsoever in the other regions. Care-giving outside the household, taking an educational course and participating in a political organisation have neither a substantially nor statistically significant effect under any welfare regime. Finally, physical activity is slightly beneficial on the border of $p=0.05$ with virtually identical coefficients between 0.326 and 0.348 in all regions. Generally, the impact of roles on QoL differs across Europe, but the overall effects are rather small and almost negligible compared to the effects of age and economic conditions.

\section{Conclusion and discussion}

This paper examines the effect of roles supported by an active ageing approach on subjective QoL and the differences between these effects based on differences across European macro-regions that reflect different socio-economic, cultural and institutional contexts. This topic is crucial amidst the extensive support of the tested activities by the active ageing policies due to its proclaimed uniform contribution to the QoL of older adults (Walker, 2009; United Nations Economic Commission for Europe and European Commission, 2015; Zaidi et al., 2017; Varlamova, 2018). The effect of specific activities has been repeatedly studied, but this research extends the current understanding by employing several novelties. These are (a) all concerned activities are included in one estimation to control for each other, (b) a within-person estimator is used to evaluate changes in panel data with control for time-invariant factors, and (c) potential differences in the effect of roles across four European regions are explored. The panel analysis of the SHARE data resulted in several empirical and theoretical contributions - namely only weak or not statistically significant beneficial effects of supported activities - elaborated below.

First, the effects of activities supported by the active ageing perspective in fixed-effects regression are much weaker or even non-existent compared to beneficial effects estimated by random-effects regression. This result suggests that the effects of REM (and of many cross-sectional studies) can be explained by some unobserved variables, such as norms of in-groups, individual values, role centrality or role meaningfulness (Hornsey, 2008; Adams et al., 2011). Furthermore, the REM and findings from previous cross-sectional studies may overestimate the association between the examined social activities and QoL. Therefore, the effect of many activities in a panel perspective - care-giving outside the household and participation in the labour force, training and political organisations - is not beneficial and the effect of care- 
giving within the household is even strongly negative. The prevailing net effect of starting or ending activity by a specific person is generally less positive than the effect in the previous studies, which usually did not adopt the more-robust methodological approach of the present paper (Walker, 2004; Katz, 2009; Siegrist and Wahrendorf, 2009; Adams et al., 2011; Potočnik and Sonnentag, 2013). The reasons for prevailingly not significant effects of roles can be (a) the use of a less-biased statistical technique based on panel data, (b) control for important activities in later life, and (c) to some extent also the lower efficiency of estimates because of a reduced sample.

Second, participation in volunteering, sports or social club, and physical activity is beneficial in FEM for the pooled sample of European countries, but their effects are not significant in some regions. The regional differences in the effect of activities suggest their context-specific role in the lives of older adults, which is not reflected by the active ageing paradigm (Timonen, 2016; de São José et al., 2017; Marsillas et al., 2017) and is mostly in line with the expectations based on the concept of structured ambivalence and the social identity theory. The substantially positive effect of labour force participation in less-prosperous regions compared to the negative effect in more-prosperous regions may thus be an outcome of the relative importance of paid work in various economic settings (Borges Neves et al., 2013; Hofäcker, 2015; Lakomý, 2019). Whilst the higher prevalence of care-giving within the household in Mediterranean countries is related to more-frequent co-residence (Jappens and Van Bavel, 2012; Albertini and Kohli, 2013), the not statistically significant negative effect of this activity in social-democratic countries may reflect the higher availability of formal care in that context (Daatland and Lowenstein, 2005; Fokkema et al., 2008; Brandt et al., 2009). The negative association of care-giving within a household with QoL in three European regions may be explained by the location of care and strength of obligations (Lee et al., 2020). Another explanation could be the adverse effect on QoL in measured domains of autonomy and control over life (Di Novi et al., 2015). In contrast to the expected role of availability of formal care, the strength of familial norms does not correlate with the outcomes of care-giving as expected by the concept of structured ambivalence (Connidis and McMullin, 2002a, 2002b), as the effect of care-giving outside the household is not more positive in the Mediterranean and post-communist countries. Finally, stronger civic norms could account for the positive effect of volunteering in social-democratic countries based on the higher social appreciation of these activities and lower structured ambivalence, if they are performed (Neuberger and Haberkern, 2014).

Third, the weak and unstable outcomes of activities can be contrasted with the effect of age, economic situation, education and health on QoL, which is strong and robust. Hence, income security and availability of health care form subjective QoL in later life much more than additional roles. Although health and income may be strengthened by some types of activities (Thomas, 2011; Hofäcker and Naumann, 2015), availability of resources and services seems impossible to replace in the quest for an improvement of QoL (Rozanova et al., 2012; Timonen, 2016).

Fourth, the paper argues that the active ageing approach is based on normative and empirically dubious assumptions. The presented findings challenge those of active ageing policy, but also their theoretical underpinnings in the form of the active ageing concept and the activity theory. Especially serious consequences has the active ageing approach as an official social policy approach to the ageing of 
the EU, which needs to be revisited according to the findings of (not only) this study. The process of revising concerns also activity theory, which needs to accept that only meaningful and freely chosen activities are beneficial (Adams et al., 2011; Rozanova et al., 2012) and this paper illustrates that the overall effect of activities is not substantial. More valid proved to be the social identity theory, which makes it possible to explain varying outcomes of activities with different meanings such as volunteering and participation in social clubs - by social group norms and salience. Finally, the concept of structured ambivalence (Connidis and McMullin, $2002 b$ ) is beneficial for explaining the contextual variance in activity outcomes such as the positive effect of volunteering in countries with stronger civic norms. These approaches address much better both the variation of activity outcomes and a call for replacing 'absolute notions' of social gerontology by probabilistic theories (George, 1993; Phillips et al., 2010) and for a probabilistic rather than causal approach regarding later-life concepts, which could end the theory-poor state of this field (Moulaert et al., 2018). In sum, this paper argues that social research and social policies should reflect the varying - and generally weak - effects of activities in later life identified in this study and consider revising its theoretical underpinnings.

Most limitations of this study stem from the nature of the data, originally not collected for the purposes of the study. First, most of the activities were measured by one closed item used as a binary variable in the analysis. As a result, the regression model distinguishes neither the frequency of the activity nor further details on its particular form. Second, a mild within-person variability of some explanatory variables may contribute to some unstable or not significant fixed effects. Third, the poor availability of panel data means that each European region is represented only by two, thre, or four countries. These countries within regions are similar in many respects but still contain hidden variation. Additionally, no country-level indicators in the data decrease the applicability of the structured ambivalence concept. Finally, fixed-effects regression performed on the panel data does not eliminate all sources of possible selection or endogeneity bias. Despite these reflected limitations, the paper presents the results that are important for research on QoL in older ages and for European social policies aiming to increase this QoL. Nevertheless, more research is needed to test and develop the findings of this study in further comparative, longitudinal and multilevel studies.

Data. This paper uses data from SHARE Waves 4, 5 and 6 (DOIs: 10.6103/SHARE.w4.600, 10.6103/ SHARE.w5.600, 10.6103/SHARE.w6.600), see Börsch-Supan et al. (2013) for methodological details. The SHARE data collection has been primarily funded by the European Commission through FP5 (QLK6-CT-2001-00360), FP6 (SHARE-I3: RII-CT-2006-062193, COMPARE: CIT5-CT-2005-028857, SHARELIFE: CIT4-CT-2006-028812) and FP7 (SHARE-PREP: No. 211909, SHARE-LEAP: No. 227822, SHARE M4: No. 261982). Additional funding from the German Ministry of Education and Research, the Max Planck Society for the Advancement of Science, the US National Institute on Aging (U01_AG09740-13S2, P01_AG005842, P01_AG08291, P30_AG12815, R21_AG025169, Y1-AG-4553-01, IAG_BSR06-11, OGHA_04-064, HHSN271201300071C) and from various national funding sources is gratefully acknowledged (see www.share-project.org).

Acknowledgements. The author would like to acknowledge Martin Kreidl (Masaryk University) for valuable advice and vigorous commenting on this study. The author would also like to thank the anonymous reviewers and the editor Valeria Bordone for a repeated careful consideration of this study and its significant improvement. 


\section{References}

Adams KB, Leibbrandt S and Moon H (2011) A critical review of the literature on social and leisure activity and wellbeing in later life. Ageing \& Society 31, 683-712.

Albertini M and Kohli M (2013) The generational contract in the family: an analysis of transfer regimes in Europe. European Sociological Review 29, 828-841.

Allison PD (2005) Causal inference with panel data. Paper presented at the American Sociological Annual Meeting, August 13-16, Philadelphia. Available at https://statisticalhorizons.com/wp-content/uploads/ 2012/01/Causal-Inference.pdf

Allison PD (2009) Fixed Effects Regression Models. Los Angeles, CA: Sage.

Arpino B and Bordone V (2017) Regular provision of grandchild care and participation in social activities. Review of Economics of the Household 15, 135-174.

Arpino B and Bordone V (2018) Active ageing typologies: a latent class analysis of the older Europeans. In Zaidi A, Harper S, Howse K, Lamura G and Perek-Białas J (eds), Building Evidence for Active Ageing Policies: Active Ageing Index and Its Potential. Singapore: Palgrave Macmillan, pp. 295-311.

Atchley RC (1989) A continuity theory of normal aging. The Gerontologist 29, 183-190.

Axelrad H, Malul M and Luski I (2018) Unemployment among younger and older individuals: does conventional data about unemployment tell us the whole story? Journal for Labour Market Research 52, 3.

Baltes PB and Smith J (2003) New frontiers in the future of ageing: from successful ageing of young old to the dilemmas of the fourth age. Gerontology 49, 123-135.

Bell A, Fairbrother M and Jones K (2019) Fixed and random effects models: making an informed choice. Quality and Quantity 53, 1051-1074.

Borges Neves R, Barbosa F, Matos AD, Rodrigues V and Machado J (2013) Unemployed 50+: exploring risk factors for depression in Europe. In Börsch-Supan A, Brandt M, Litwin H and Weber G (eds), Active Ageing and Solidarity Between Generations in Europe: First Results from SHARE After the Economic Crisis. Berlin: De Gruyter, pp. 91-100.

Borrat-Besson C, Ryser V-A and Gonçalves J (2015) An evaluation of the CASP-12 scale used in the Survey of Health, Ageing and Retirement in Europe (SHARE) to measure quality of life among people aged 50+. FORS, Lausanne, FORS Working Paper Series 30.

Börsch-Supan A (2017) Survey of Health, Ageing and Retirement in Europe (SHARE) Wave 5. Release version 6.0.0. SHARE-ERIC (Dataset).

Börsch-Supan A, Brandt M, Hunkler C, Kneip T, Korbmacher J, Malter F, Schaan B, Stuck S and Zuber S (2013) Data resource profile: the Survey of Health, Ageing and Retirement in Europe (SHARE). International Journal of Epidemiology 42, 992-1001.

Brandt M, Haberkern K and Szydlik M (2009) Intergenerational help and care in Europe. European Sociological Review 25, 585-601.

Broese van Groenou MI, de Boer A and Iedema J (2013) Positive and negative evaluation of caregiving among three different types of informal care relationships. European Journal of Ageing 10, 301-311.

Brüderl J and Ludwig V (2015) Fixed-effects panel regression. In Best H and Wolf C (eds). The Sage Handbook of Regression Analysis and Causal Inference. Los Angeles, CA: Sage, pp. 327-357.

Bryan ML and Jenkins SP (2016) Multilevel modelling of country effects: a cautionary tale. European Sociological Review 32, 3-22.

Burr JA, Choi NG, Mutchler JE and Caro FG (2005) Caregiving and volunteering: are private and public helping behaviors linked? Journals of Gerontology: Psychological Sciences and Social Sciences 60B, 247-256.

Burr JA, Mutchler JE and Caro FG (2007) Productive activity clusters among middle-aged and older adults: intersecting forms and time commitments. Journals of Gerontology: Psychological Sciences and Social Sciences 62B, S267-S275.

Cattan M, Hogg E and Hardill I (2011) Improving quality of life in ageing populations: what can volunteering do? Maturitas 70, 328-332.

Cohen J, Cohen P, West SG and Aiken LS (2003) Applied Multiple Regression/Correlation Analysis for the Behavioural Sciences. Mahwah, NJ: Lawrence Erlbaum Associates.

Colombo F, Llena-Nozal A, Mercier J and Tjadens F (2011) Help Wanted? Providing and Paying for Long-term Care. Paris: OECD Publishing.

Commission of the European Communities (2002) Europe's Response to World Ageing: Promoting Economic and Social Progress in an Ageing World. Brussels: Commission of the European Communities. 
Connidis IA and McMullin JA (2002a) Ambivalence, family ties, and doing sociology. Journal of Marriage and Family 64, 594-601.

Connidis IA and McMullin JA (2002b) Sociological ambivalence and family ties: a critical perspective. Journal of Marriage and Family 64, 558-567.

Curtis JE, Baer DE and Grabb EG (2001) Nations of joiners: explaining voluntary association membership in democratic societies. American Sociological Review 66, 783-805.

Daatland SO and Lowenstein A (2005) Intergenerational solidarity and the family-welfare state balance. European Journal of Ageing 2, 174-182.

Daatland SO, Veenstra M and Lima IA (2010) Norwegian sandwiches: on the prevalence and consequences of family and work role squeezes over the life course. European Journal of Ageing 7, 271-281.

De São José JM, Timonen V, Amado CAF and Santos SP (2017) A critique of the Active Ageing Index. Journal of Aging Studies 40, 49-56.

Di Gessa G and Grundy E (2013) The relationship between active ageing and health using longitudinal data from Denmark, France, Italy and England. Journal of Epidemiology and Community Health 68, 261-267.

Di Novi C, Jacobs R and Migheli M (2015) The quality of life of female informal caregivers: from Scandinavia to the Mediterranean Sea. European Journal of Population 31, 309-333.

Ebbinghaus B (2012) Comparing welfare state regimes: are typologies an ideal or realistic strategy? Paper presented at the ESPAnet Conference, September 6-8, Edinburgh.

Eikemo TA, Bambra C, Judge K and Ringdal K (2008) Welfare state regimes and differences in selfperceived health in Europe: a multilevel analysis. Social Science \& Medicine 66, 2281-2295.

Engelhardt H, Buber I, Skirbekk V and Prskawetz A (2010) Social involvement, behavioural risks and cognitive functioning among older people. Ageing \& Society 30, 779-809.

Esping-Andersen G (1990) Three Worlds of Welfare Capitalism. Princeton, NJ: Princeton University Press.

EU Council (2012) Council Declaration on the European Year for Active Ageing and Solidarity Between Generations (2012): The Way Forward. Brussels: EU Council.

European Commission (2013) Introducing the Active Ageing Index. Policy Brief. Brussels: European Commission.

Eurostat (2012) Active Ageing and Solidarity Between Generations: A Statistical Portrait of the European Union 2012. Luxembourg: Publications Office of the European Union.

Fenger M (2007) Welfare regimes in Central and Eastern Europe: incorporating post-communist countries in a welfare regime typology. Contemporary Issues and Ideas in Social Sciences 3, 1-30.

Ferrera M (1996) The 'southern model' of welfare in social Europe. Journal of European Social Policy 6, 17-37.

Fokkema T, ter Bekke S and Dykstra P (2008) Solidarity Between Parents and Their Adult Children in Europe. Amsterdam: Amsterdam University Press.

Foster L and Walker A (2015) Active and successful aging: a European policy perspective. The Gerontologist 55, 83-90.

George LK (1993) Sociological-perspectives on life transitions. Annual Review of Sociology 19, 353-373.

Gergen MM and Gergen KJ (2006) Positive aging: reconstructing the life course. In Worell J and Goodheart CD (eds), Handbook of Girls' and Women's Psychological Health: Gender and Well-being Across the Life Span. Oxford: Oxford University Press, pp. 416-426.

Gjonça E, Stafford M, Zaninotto P, Nazroo J and Wood N (2010) Health and social engagement among the oldest old. In Banks J, Lessof C, Nazroo J, Rogers N, Stafford M and Steptoe A (eds), Financial Circumstances, Health and Well-being of the Older Population in England: The 2008 English Longitudinal Study of Ageing (Wave 4). London: The Institute for Fiscal Studies, pp. 227-253.

Goode WJ (1960) A theory of role strain. American Sociological Review 25, 483-496.

Gorry A, Gorry D and Slavov S (2015) Does retirement improve health and life satisfaction? National Bureau of Economic Research, Cambridge, MA, NBER Working Paper 21326.

Gunasekara FI, Richardson K, Carter K and Blakely T (2014) Fixed effects analysis of repeated measures data. International Journal of Epidemiology 43, 264-269.

Hanchane S and Mostafa T (2012) Solving endogeneity problems in multilevel estimation: an example using education production functions. Journal of Applied Statistics 39, 1101-1114.

Hank K (2011) Societal determinants of productive aging: a multilevel analysis across 11 European countries. European Sociological Review 27, 526-541. 
Hansen T and Slagsvold B (2016) Late-life loneliness in 11 European countries: results from the Generations and Gender Survey. Social Indicators Research 129, 445-464.

Havighurst RJ (1961) Successful aging. The Gerontologist 1, 8-13.

Hess M, Nauman E and Steinkopf L (2017) Population ageing, the intergenerational conflict, and active ageing policies - a multilevel study of 27 European countries. Journal of Population Ageing 10, 11-23.

Higgs P, Hyde M, Wiggins R and Blane D (2003) Researching quality of life in early old age: the importance of the sociological dimension. Social Policy \& Administration 37, 239-252.

Hofäcker D (2015) In line or at odds with active ageing policies? Exploring patterns of retirement preferences in Europe. Ageing \& Society 35, 1529-1556.

Hofäcker D and Naumann E (2015) The emerging trend of work beyond retirement age in Germany. Zeitschrift für Gerontologie und Geriatrie 48, 473-479.

Hogg MA (2016) Social identity theory. In McKeown S, Haji R and Ferguson N (eds), Understanding Peace and Conflict Through Social Identity Theory. Cham, Switzerland: Springer, pp. 3-17.

Hooghe M, Oser J and Marien S (2016) A comparative analysis of 'good citizenship': a latent class analysis of adolescents' citizenship norms in 38 countries. International Political Science Review 37, 115-129.

Horner EM (2014) Subjective well-being and retirement: analysis and policy recommendations. Journal of Happiness Studies 15, 125-144.

Hornsey MJ (2008) Social identity theory and self-categorization theory: a historical review. Social and Personality Psychology Compass 2, 204-222.

Hyde M, Wiggins RD, Higgs P and Blane DB (2003) A measure of quality of life in early old age: the theory, development and properties of a needs satisfaction model (CASP-19). Aging \& Mental Health 7, 186-194.

Jappens M and Van Bavel J (2012) Regional family norms and child care by grandparents in Europe. Demographic Research 27, 85-120.

Kammer A, Niehues J and Peichl A (2012) Welfare regimes and welfare state outcomes in Europe. Journal of European Social Policy 22, 455-471.

Kaschowitz J and Brandt M (2017) Health effects of informal caregiving across Europe: a longitudinal approach. Social Science and Medicine 173, 72-80.

Katz R (2009) Intergenerational family relations and subjective well-being in old age: a cross-national study. European Journal of Ageing 6, 79-90.

Krause N (2007) Age and decline in role-specific feelings of control. Journals of Gerontology: Psychological Sciences and Social Sciences 62B, S28-S35.

Lakomý M (2019) The effects of prolonged working life on subjective quality of life across Europe. Social Science Research 82, 33-44.

Lakomý M (2020) Is providing informal care a path to meaningful and satisfying ageing? European Societies 22, 101-121.

Lakomý M and Kreidl M (2015) Full-time versus part-time employment: does it influence frequency of grandparental childcare? European Journal of Ageing 12, 321-331.

Lakomý M and Petrová Kafková M (2017) Resilience as a factor of longevity and gender differences in its effects. Sociologický Časopis/Czech Sociological Review 53, 369-392.

Latif E (2011) The impact of retirement on mental health in Canada. Journal of Mental Health Policy and Economics 16, 35-46.

Lee Y, Bierman A and Penning M (2020) Psychological well-being among informal caregivers in the Canadian Longitudinal Study on Aging: why the location of care matters. Journals of Gerontology: Psychological Sciences and Social Sciences 75B, 2207-2218.

Madero-Cabib I and Kaeser L (2016) How voluntary is the active ageing life? A life-course study on the determinants of extending careers. European Journal of Ageing 13, 25-37.

Maestas N and Li X (2006) Discouraged workers? Job search outcomes of older workers. Michigan Retirement Research Center Research Working Paper 2006-133.

Marsillas S, De Donder L, Kardol T, van Regenmortel S, Dury S, Brosens D, Smetcoren AS, Braña T and Varela J (2017) Does active ageing contribute to life satisfaction for older people? Testing a new model of active ageing. European Journal of Ageing 14, 295-310.

Maslow AH (1943) A theory of human motivation. Psychological Review 50, 370-396.

Merton RK (1976) Sociological Ambivalence and Other Essays. New York, NY: The Free Press. 
Moulaert T, Wanka A and Drilling M (2018) The social production of age, space and exclusion: towards a more theory-driven understanding of spatial exclusion mechanisms in later life. Sociální Studia/Social Studies 15, 9-23.

Musick MA and Wilson J (2003) Volunteering and depression: the role of psychological and social resources in different age groups. Social Science and Medicine 56, 259-269.

Neuberger FS and Haberkern K (2014) Structured ambivalence in grandchild care and the quality of life among European grandparents. European Journal of Ageing 11, 171-181.

Nikolova M, Roman M and Zimmermann KF (2017) Left behind but doing good? Civic engagement in two post-socialist countries. Journal of Comparative Economics 45, 658-684.

Nimrod G (2007) Expanding, reducing, concentrating and diffusing: post retirement leisure ehaviour and life satisfaction. Leisure Sciences 29, 91-111.

Olesen SC and Berry HL (2011) Community participation and mental health during retirement in community sample of Australians. Aging \& Mental Health 15, 186-197.

Paúl C, Ribeiro O and Teixeira L (2012) Active ageing: an empirical approach to the WHO model. Current Gerontology and Geriatrics Research 2012, 382972.

Phillips J, Ajrouch K and Hillcoat-Nallétamby S (2010) Key Concepts in Social Gerontology. Los Angeles, CA: Sage.

Pines AM, Neal MB, Hammer LB and Icekson T (2011) Job burnout and couple burnout in dual-earner couples in the sandwiched generation. Social Psychology Quarterly 74, 361-386.

Platts LG, Webb E, Zins M, Goldberg M and Netuveli G (2015) Mid-life occupational grade and quality of life following retirement: a 16-year follow-up of the French GAZEL study. Aging \& Mental Health 19, 634-646.

Potočnik K and Sonnentag S (2013) A longitudinal study of well-being in older workers and retirees: the role of engaging in different types of activities. Journal of Occupational and Organizational Psychology 86, 497-521.

Reichert M and Weidekamp-Maicher M (2004) Germany - quality of life in old age II. In Walker A (ed.), Growing Older in Europe. Maidenhead, UK: Open University Press, pp. 159-178.

Rife JC and First RJ (1989) Discouraged older workers: an exploratory study. International Journal of Aging and Human Development 29, 195-203.

Rowe JW and Kahn RL (2015) Successful aging 2.0: conceptual expansions for the $21^{\text {st }}$ century. Journals of Gerontology: Psychological Sciences and Social Sciences 70B, 593-596.

Rozanova J, Keating N and Eales J (2012) Unequal social engagement for older adults: constraints on choice. Canadian Journal on Aging/La Revue canadienne du vieillissement 31, 25-36.

Salomon JA, Wang H, Freeman MK, Vos T, Flaxman AD, Lopez AD and Murray CJL (2012) Healthy life expectancy for 187 countries, 1990-2010: a systematic analysis for the Global Burden Disease Study 2010. The Lancet 380, 2144-2162.

Sets JE and Burke PJ (2010) Identity theory and social identity theory. Social Psychology 63, 224-237.

Sidorenko A and Zaidi A (2013) Active ageing in CIS countries: semantics, challenges, and responses. Current Gerontology and Geriatrics Research 2013, 261819.

Sieber SD (1974) Toward a theory of role accumulation. American Sociological Review 39, 567-578.

Siegrist J and Wahrendorf $\mathbf{M}$ (2009) Participation in socially productive activities and quality of life in early old age: findings from SHARE. Journal of European Social Policy 19, 317-326.

Sirovátka T, Guzi M and Saxonberg S (2019) Satisfaction with democracy and perceived performance of the welfare state in Europe. Journal of European Social Policy 29, 241-256.

Tajfel H and Turner J (1979) An integrative theory of intergroup conflict. In Austin WG and Worchel S (eds), Organizational Identity: A Reader. Monterey, CA: Brooks/Cole, pp. 33-47.

Thomas PA (2011) Trajectories of social engagement and limitations in late life. Journal of Health and Social Behavior 52, 430-443.

Thomas PA (2012) Trajectories of social engagement and mortality in late life. Journal of Aging and Health 24, 547-568.

Timonen V (2016) Beyond Successful and Active Ageing: A Theory of Model Ageing. Bristol, UK: Policy Press.

Trading Economics (2017) Retirement Age of Men and Women. Available at https://tradingeconomics. com/country-list/retirement-age-women

United Nations (2013) Ensuring a society for all ages: promoting quality of life and active ageing. In 2012 UNECE Ministerial Conference on Ageing. Geneva: United Nations, pp. iii-71. 
United Nations Economic Commission for Europe and European Commission (2015) Active Ageing Index 2014: Analytical Report. Geneva: United Nations Economic Commission for Europe.

Varlamova M (2018) Active Ageing Index (AAI) in Non-EU Countries and at Subnational Level: Guidelines. Geneva and Brussels: United Nations Economic Commission for Europe and European Commission.

Vidovićová L (2018) The expected, evaluated, perceived, valued and prevalent social roles of older people: are they by consent? In Zaidi A, Harper S, Howse K, Lamura G and Perek-Białas J (eds), Building Evidence for Active Ageing Policies: Active Ageing Index and Its Potential. Singapore: Palgrave Macmillan, pp. 39-54.

Walker A (2002) The politics of intergenerational relations. Zeitschrift für Gerontologie und Geriatrie 35, 297-303.

Walker A (2004) Quality of life in old age in Europe. In Walker A (ed.), Growing Older in Europe. Maidenhead, UK: Open University Press, pp. 1-30.

Walker A (2005) A European perspective on quality of life in old age. European Journal of Ageing 2, 2-12.

Walker A (2009) Commentary: The emergence and application of active aging in Europe. Journal of Aging and Social Policy 21, 75-93.

Walker A and Maltby T (2012) Active ageing: a strategic policy solution to demographic ageing in the European Union. International Journal of Social Welfare 21, 117-130.

Wiertz D and Lim C (2019) The civic footprints of labor market participation: longitudinal evidence from the United States, 2002-2015. Social Forces 97, 1757-1784.

Windmeijer F (2000) Moment conditions for fixed effects count data models with endogenous regressors. Economics Letters 68, 21-24.

World Health Organization (WHO) (2002) Active Ageing: A Policy Framework. Geneva: WHO.

Zaidi A and Howse K (2017) The policy discourse of active ageing: some reflections. Journal of Population Ageing 10, 1-10.

Zaidi A, Gasior K, Zolyomi E, Schmidt A, Rodrigues R and Marin B (2017) Measuring active and healthy ageing in Europe. Journal of European Social Policy 27, 138-157.

Zaidi A, Harper S, Howse K, Lamura G and Perek-Białas J (2018a) Towards an evidence-based active ageing strategy. In Zaidi A, Harper S, Howse K, Lamura G and Perek-Białas J (eds), Building Evidence for Active Ageing Policies: Active Ageing Index and Its Potential. Singapore: Palgrave Macmillan, pp. 1-16.

Zaidi A, Harper S, Howse K, Lamura G and Perek-Białas J (eds) (2018b) Building Evidence for Active Ageing Policies: Active Ageing Index and Its Potential. Singapore: Palgrave Macmillan.

Cite this article: Lakomý M (2023). The effect of roles prescribed by active ageing on quality of life across European regions. Ageing \& Society 43, 664-688. https://doi.org/10.1017/S0144686X21000726 